\title{
Trichome diversity studies in selected species of Sida
}

\author{
G. Ashwathy, K. Krishnakumar* \\ Nutraceutical Research Division, Post Graduate and Research Department of Botany, Maharaja's College \\ (Government Autonomous), Ernakulam- 682011, Kerala, India
}

Received: March 23, 2020 Revised: May 27, 2020 Accepted: May 29, 2020 Published: June 16, 2020

*Corresponding Author: K. Krishnakumar Email:kkrishnakumar.alp@ gmail.com

\begin{abstract}
Sida (Family: Malvaceae) belongs to the genus of flowering plants that possess high medicinal value and is used traditionally in almost all parts of the world. There were about 18 species reported from the state of Kerala (India). Among these, some are with taxonomic controversies. Hence micro-morphological characters of leaves such as trichomes can be used as a taxonomic tool for the identification of plants. Their type, presence, absence and distribution are important diagnostic characters in plant identification and plant taxonomy. Plant samples were collected from different localities of Kerala. Foliar epidermal studies were carried out in order to identify the diversity and distribution of trichomes in the selected species of Sida viz., S. acuta, S. alnifolia, S. beddomei, S. cordata, S. cordifolia, S. fryxelli, S. ravii, S. rhombifolia and S. rhomboidea. Six types of trichomes were identified; they were stellate, conical, forked, capitate (short stalked), uniseriate multicellular and peltate. Stellate trichomes were observed in all the species. Conical trichomes were observed in S. beddomei, S cordata and S. fryxelli. Forked trichome was observed in S. acuta, S. cordata, S. cordifolia, S. ravii, S. rhombifolia and S. rhomboidea. Capitate (short stalked) trichomes were observed in S. acuta, S. alnifolia, S. rhombifolia and S. rhomboidea. Uniseriate multicellular trichomes were observed in S. cordifolia, S. fryxelli and S. ravii. Peltate trichomes are observed in all species except S. beddomei, S. cordifolia and S. fryxelli. However, these species could be easily distinguished by their conical trichomes. A bracketed dichotomous key was prepared for the identification of the species considered for the study.
\end{abstract}

KEYWORDS: Sida, Trichomes, Stellate, Forked, Capitate, Conical

\section{INTRODUCTION}

Sida is a genus of Angiosperms that belongs to the Family Malvaceae. The name Sida was proposed by Linnaeus in 1753 in 'Species Plantarum'. The genus is represented by 200 species around the world, more than 20 species in India and 18 species in Kerala [1-6]. Species of Sida has been traditionally used in Ayurvedic, Siddha, Unani, and Homeopathic system of medicine. It is the most widely used raw drug in the treatment of rheumatism. It is also used in the treatment of neurological disorders, headache, leucorrheal tuberculosis, diabetes, fever and uterine disorders [7\&8]. They are perennial herbs or subshrubs, erect or prostrate, glabrous or pubescent, sometimes viscid. Most of them are heliophilous weedy taxa growing in exposed waste lands. But occasionally, they do occur also as under-growths in semi-deciduous and deciduous forests, plantations and in partially shaded habitats [2].

Sida was heterogeneous taxa from the period of Theophrastus, as the generic name was used to denote Nymphaea and other aquatic plants at that point of time. It was Linnaeus who restricted the genus to Malvaceous members [2]. Although earlier works reports the presence of only 150- 200 species distributed worldwide, more than 1000 names have been published in the genus. Hence, there are taxonomic complexities within the genus. Various researchers have worked to unravel the complexities by studying characters of leaves [9\&10]. Leaves are usually neglected organs in taxonomic and comparative morphological studies. Leaf morphological and anatomical characters can be of great taxonomic significance. As Metcalfe and Chalk [11] reported, leaves are considered as the most varied organ anatomically in angiosperms which provides a variety of anatomical features that can be employed as useful taxonomic characters. Foliar anatomical characters like stomata and trichomes are found instrumental in solving taxonomic problems and its significance have long been recognized by various workers [12].

Trichomes are epidermal appendages of varying shape, structure, and function. They are found in almost all plant parts ie., leaves, petals, stalks, peduncles, stems and seeds coat surfaces. Leaf trichomes have been shown to scale back herbivory in a number of plant species [13\&14]. Trichomes are of great importance 
to the plants as they are used for reducing leaf temperature, increasing light reflectance degree, preventing desiccation and reducing frictional force on the leaves [15]. Gulzar et al. [16], have described the importance of the structure and nature of trichomes in phylogeny. There are also previous works mentioning that the abundance of particular trichome type may aid in taxonomic studies of genera, species and plant families [11\&17].

The present investigation is aimed to spot the range and distribution of trichomes within the selected species of Sida viz., S. acuta, S. alnifolia, S. cordata, S. cordifolia, S. fryxelli, S. ravii, S. rhombifolia and S. rhomboidea. to easily delineate the different species.

\section{MATERIALS AND METHODS}

1. Collection and identification of plant specimens

Field explorations were carried out in different parts of Kerala (India) and 9 species of Sida were collected (Table 1). The collected specimens were identified using standard authentic literature [1,2\&3].

2. Trichome study

Foliar anatomical sections were carried out to identify the distribution and diversity of trichomes in Sida species. Leaf samples were taken from each species and free hand sections were taken. The sections were stained using $1 \%$ aqueous solution of safranin. Excess stain was washed off with water. The sections of each species were mounted in glycerin and observed under the light microscope with 40X resolution (Biolinkz M2000 series). The types of trichomes for each species were noted and photographs were taken.

\section{RESULTS}

As a result of field exploration, 9 species of Sida were collected. The details of the collected samples are given in Table 1.

Foliar epidermal studies were carried out in order to identify the diversity and distribution of trichomes in the selected species of Sida viz., S. acuta, S. alnifolia, S. beddomei, S. cordata, S. cordifolia, S. fryxelli, S. ravii, S. rhombifolia and S. rhomboidea. There were six types of trichomes identified in the species of Sida studied viz., conical(simple), forked, stellate, capitate (short stalked), uniseriate multicellular and peltate (Table 2). Stellate trichomes were observed in all the species. Conical trichomes were observed in S. beddomei, S cordata and S. fryxelli. Forked trichome was observed in S. acuta, S. cordata, S. cordifolia, S. ravii, S. rhombifolia and S. rhomboidea. Capitate (short stalked) trichomes were observed in S. acuta, S. alnifolia, S. rhombifolia and S. rhomboidea. Uniseriate multicellular trichomes were observed in S. cordifolia, S. fryxelli and S. ravii. Peltate trichomes are observed in all species except $S$. beddomei, S. cordifolia and S. fryxelli. Trichome distribution in Sida species is given in Table 3.

A bracketed dichotomous key was prepared for the 9 species of Sida studied. The key is given below:
Table 1: List of Sida species collected for the study

\begin{tabular}{|c|c|c|}
\hline SI. No. & Species of Sida & Localities \\
\hline 1. & Sida acuta Burm. F. & $\begin{array}{l}\text { Panampilly Nagar (Ernakulam Dist.), } \\
\text { Eramalloor (Alappuzha Dist.), Peechi } \\
\text { (Thrissur Dist.) }\end{array}$ \\
\hline 2. & Sida alnifolia L. & $\begin{array}{l}\text { North Paravoor (Ernakulam Dist.), } \\
\text { Bhoothathankettu (Ernakulam Dist.) }\end{array}$ \\
\hline 3. & $\begin{array}{l}\text { Sida beddomei } \\
\text { Jacob. }\end{array}$ & Bhoothathankettu (Ernakulam Dist.) \\
\hline 4. & $\begin{array}{l}\text { Sida cordata (Burm. } \\
\text { f.) Bross. Waalk. }\end{array}$ & $\begin{array}{l}\text { Peechi (Thrissur Dist.), Eramalloor } \\
\text { (Alappuzha Dist.) }\end{array}$ \\
\hline 5. & Sida cordifolia L. & Cherthala (Alappuzha Dist.) \\
\hline 6. & $\begin{array}{l}\text { Sida fryxelli Sivar. \& } \\
\text { Pradeep. }\end{array}$ & $\begin{array}{l}\text { North Paravoor (Ernakulam Dist.), } \\
\text { Eramalloor (Alappuzha Dist.) }\end{array}$ \\
\hline 7. & Sida rhombifolia L. & $\begin{array}{l}\text { Panampilly Nagar (Ernakulam Dist.), } \\
\text { Paravoor (Ernakulam Dist.), Eramalloor } \\
\text { (Alappuzha Dist.), Peechi (Thrissur Dist.) }\end{array}$ \\
\hline 8. & $\begin{array}{l}\text { Sida rhomboidea } \\
\text { Roxb. ex. Flemming. }\end{array}$ & Panampilly Nagar (Ernakulam Dist.) \\
\hline 9. & $\begin{array}{l}\text { Sida ravii Sivad. \& } \\
\text { Anil Kumar }\end{array}$ & Maruthoorkulangara (Kollam Dist.) \\
\hline
\end{tabular}

Table 2: Types of Trichomes identified in Sida species

\begin{tabular}{|c|c|c|}
\hline SI. No. & Type of Trichomes & Description \\
\hline 1. & Conical (simple) & $\begin{array}{l}\text { Axillary elongated, unicellular, broad at the } \\
\text { base and tapering above }\end{array}$ \\
\hline 2. & Forked & Two ray cells present in the same cell cavity \\
\hline 3. & Stellate & $\begin{array}{l}\text { Formed of considerable number of ray cells } \\
\text { held together in the center }\end{array}$ \\
\hline 4. & $\begin{array}{l}\text { Capitate (Short } \\
\text { stalked) }\end{array}$ & $\begin{array}{l}\text { Flask shaped with a multicellular bulging } \\
\text { base, short stalk and an oval shaped head. }\end{array}$ \\
\hline 5. & $\begin{array}{l}\text { Uniseriate } \\
\text { multicellular }\end{array}$ & $\begin{array}{l}\text { Uniseriate, Erect, formed of single row of } \\
\text { cells. Number of cells vary } 4-5\end{array}$ \\
\hline 6. & Peltate & $\begin{array}{l}\text { Sessile, cup shaped or rounded with narrow } \\
\text { apical opening }\end{array}$ \\
\hline
\end{tabular}

1. Forked

la. peltate

Capitate (short stalked)............. S. acuta, S. rhombifolia, S. rhomboidea

Conical .............................. S. cordata

Uniseriate multicellular ............. S. ravii

lb. not peltate

Uniseriate multicellular ............. S. cordifolia

2. Not forked

2a. peltate

Short stalked, capitate ............... S. alnifolia

2b. not peltate

Uniseriate multicellular ............. S. fryxelli

Conical ............................. S. beddomei

\section{DISCUSSION}

Sida is a medicinally important genus and many species belonging to the genus have been traditionally used in India since long. It is a heterogenous taxa with many taxonomic controversies. As mentioned earlier, leaves are generally neglected organs in taxonomic and comparative morphological studies. Studies on leaf architecture of dicotyledons by Hickey [18] have created much interest in the leaf characters as an aid in resolving taxonomic problems. The present 
Table 3: Trichome distribution in Sida species investigated

\begin{tabular}{|c|c|c|c|c|c|c|c|}
\hline SI. No. & Species & Conical & Forked & Stellate & Short stalked capitate & Uniseriate multicellular & Peltate \\
\hline 1. & S. acuta & & $\checkmark$ & $\checkmark$ & $\checkmark$ & & $\checkmark$ \\
\hline 2. & S. alnifolia & & & $\checkmark$ & $\checkmark$ & & $\checkmark$ \\
\hline 3. & S. beddomei & $\checkmark$ & & $\checkmark$ & & & \\
\hline 4. & S. cordata & & $\checkmark$ & $\checkmark$ & & & $\checkmark$ \\
\hline 5. & S. cordifolia & $\checkmark$ & $\checkmark$ & $\checkmark$ & & $\checkmark$ & \\
\hline 6. & S. fryxelli & $\checkmark$ & & $\checkmark$ & & $\checkmark$ & \\
\hline 7. & S. rhombifolia & & $\checkmark$ & $\checkmark$ & $\checkmark$ & & $\checkmark$ \\
\hline 8. & S. rhomboidea & & $\checkmark$ & $\checkmark$ & $\checkmark$ & & $\checkmark$ \\
\hline 9. & S. ravii & & $\checkmark$ & $\checkmark$ & & $\checkmark$ & $\checkmark$ \\
\hline
\end{tabular}

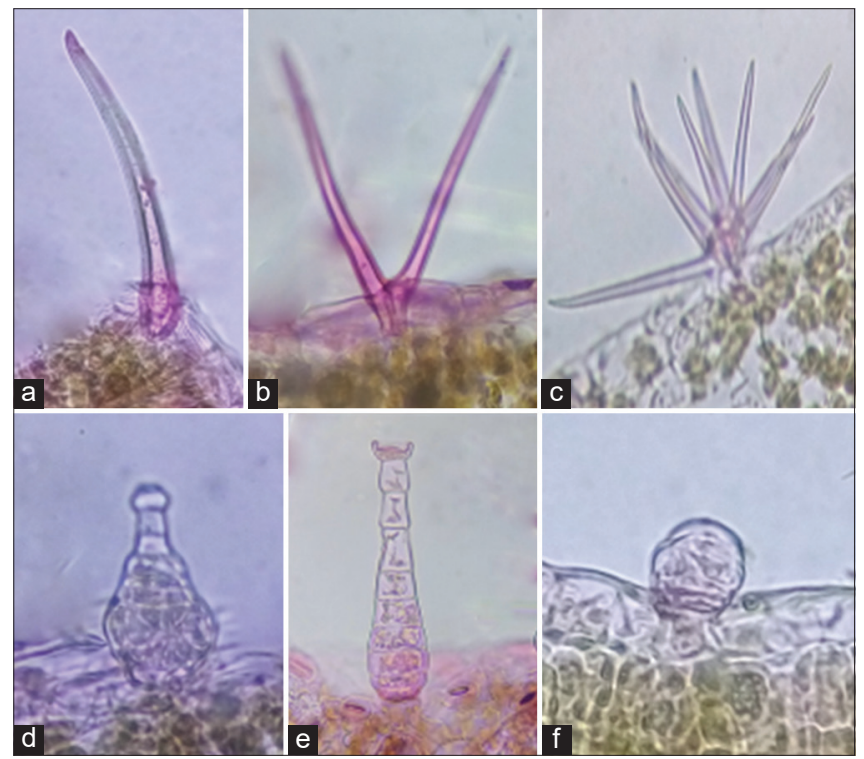

Figure 1: Photomicrographs of types of trichomes observed in Sida species. a) Conical(simple) trichome; b) Forked trichome; c) Stellate trichome; d) Capitate (short stalked) trichome; e) Uniseriate multicellular trichome; f) Peltate

study was carried out as an attempt to find out the diversity and distribution of trichomes on the leaf surface of selected species of Sida to distinguish the species. Trichomes are hair-like appendages extending from the epidermis of aerial tissues [19]. They range in different forms and sizes. In the present study, six types of trichomes were observed; viz., stellate, conical, forked, capitate (short stalked), uniseriate multicellular and peltate (Table 3). Stellate trichomes were observed in all the species. Conical trichomes were observed in $S$. beddomei, S cordata and S. fryxelli. Forked trichome was observed in S. acuta, S. cordata, S. cordifolia, S. ravii, S. rhombifolia and S. rhomboidea. Capitate (short stalked) trichomes were observed in S. acuta, S. alnifolia, S. rhombifolia and $S$. rhomboidea. Uniseriate multicellular trichomes were observed in S. cordifolia, S. fryxelli and S. ravii. Peltate trichomes are observed in all species except $S$. beddomei, $S$. cordifolia and S. fryxelli (Figure 1). Earlier studies on Sida species collected elsewhere [20] reported that peltate and stellate trichomes were found in all species under study viz., Sida alba L., S. alii S. Abedin var. alii, S. cordata (Burm. F.) Borss, S. mysorensis Wight and Arn, S. ovata Forssk. S. spinosa $\mathrm{L}$ and S. yunnanensis S.Y.Hu. Long-stalked and short-stalked capitate trichomes were observed in S. alii and S. spinosa respectively. Uniseriate multicellular trichomes were found only in S. mysorensis. This revealed that peltate and stellate trichomes are common in the genus Sida. Among the nine species studied S. beddomei, S. cordata and S. fryxelli could be easily distinguished by their characteristic conical trichomes.

An investigation on the glandular and non-glandular type of trichomes in Orthosiphon labiatus revealed that there were three types of trichome in the species under study; two glandular type (capitate and peltate) and one non- glandular type [21]. Thirteen types of trichomes were identified with Salvia nemarosa [22]; of which capitate and peltate trichomes dominated. Leaf trichome study of Hyptis suaveolens [23] revealed the presence of two types of non-glandular trichomes (monocellular and multicellular) and three types of glandular trichomes (peltate, capitate type I and capitate type II). A study conducted on the foliar epidermal characters of ten Senna species and found that Stomatal types of anisocytic, anomocytic, paracytic, tetracytic and haxacytic were found across the species, glandular trichomes were observed in S. hirsuta and S. occidentalis, while non-glandular trichomes are dominant in the remaining species[12].

Trichome diversity studies of the family Caryophyllaceae of Western Himalayas revealed the presence of six types of trichomes viz., unicellular eglandular, unicellular glandular, uulticellular uniseriate glandular, multicellular uniseriate eglandular, multicellular eglandular bifurcate and multicellular multiseriate eglandular [28]. A recent study [29] on the trichome idversity of wild and cultivated egg plants revealed that The wild species viz., S. viarum and S. mammosum have seven (Type II to VIII) morphologically distinguishable types of trichomes including two types of glandular trichomes (Type VI, VII) as against uniform occurrence of branched stellate trichomes (Type VIII) alone in cultivated species.

Earlier workers $[17,24,25,26 \& 27]$ have proved that abundance of a particular type of trichome can aid in taxonomic studies of genera, species and plant families. They carried out their work in the genus Osbeckia, family Asteraceae, Elaeis guineensis, genus Vitis, genus Hibiscus respectively. Their work had been successful in delineating the species based on leaf epidermal characters. Trichome morphological study within the genus Monardella of Lamiaceae family was used as powerful tool in differentiating taxa and resolving taxonomic ambiguities led to the revision of the genus [30]. 
In the present investigation only few species of Sida could be delineated using trichome characters. Hence further micrometry and molecular characterization studies have to be carried out in order to clearly distinguish the species of Sida. Molecular studies using marker genes like ITS1, trnH-psbA and matK are to be conducted to delineate the species.

\section{CONCLUSION}

The present study revealed the presence of six different types of trichomes in the species of Sida. They were stellate, conical, forked, capitate (short stalked), uniseriate multicellular and peltate. These results were quite useful in identifying the species up to a certain level. However, the trichome characters investigated in selected species of Sida could not delineate the species clearly. Hence, the molecular studies like DNA barcoding using different marker genes like ITS2, trnH-psbA, matK etc. have to be carried out in order to clearly delineate the species of Sida for clearing all the taxonomic controversies.

\section{ACKNOWLEDGEMENT}

The authors are grateful to Council of Scientific and Industrial Research, Government of India for financial assistance.

\section{REFRENCES}

1. Paul T. K. and M. P. Nayar. Malvaceae. In: Nayar, M. P., K. Thothathri \& M. Sanjappa (eds.), Fascicles of Flora of India, Fascicle 19. Botanical Survey of India, Calcutta, 1988; 64-233.

2. Sivarajan VV, Pradeep KA, Malvaceae of Southern Peninsular India: A taxonomic monograph Daya Publishing House, New Delhi. 1996.

3. Sivadasan M., Anil Kumar N. Sida ravii, a New Species of Malvaceae from India. Willdenowia, 1996; 25(2): 651-654.

4. Santhosh Kumar E.S., Shanavas Khan A. E, Binu S. Sida unicornis Marais (Malvaceae), A new record for India. Rheedea. 2001; 11(1): 53-56.

5. Sasidharan N. Biodiversity Documentation of Kerala, Part 6: Flowering plants. Kerala Forest Research Institute. 2004: 52-54.

6. Tambde G. M., Nimbalkar V.V., Lekhak M. M., Sardesai M. M. Sida pradeepiana sp. Nov. (Malvaceae) from India, Nordic Journal of Botany, 2016; 34: 573-577.

7. Ajithabai M.D., Rani Sunitha S. P., Jayakumar G. Review on the species of Sida used for the preparation of Nayopayam Kashayam. International Journal of Research and Reviews in Pharmacy and Applied Science, 2012; 2(2):173-195

8. Mohammad Abdul Motalib Momin, Faysal Bellah Sm, Mohammad Raussel Rahman Sarder, Ayedur Rahman Ahmed, Mohammad Monjur Murshid Gazi, Bin Emran Talha. Phytopharmacological evaluation of ethanol extract of Sida cordifolia L. roots. Asian Pacific Journal of Tropical Biomedicine. 2014; 4(1): 18-24.

9. Nighat Shaheen, Mir Ajab Khan, Ghazalah Yasmin, Muhammad Qasim Hayat, Mushtaq Ahmad, Muhammad Zafar, Asma Jabeen. Implication of foliar epidermal features in the taxonomy of Abutilon Mill. (Malvaceae). Journal of Medicinal Plants Research. 2009; 3(12): 1002-1008.

10. David Olaniran Aworinde, Bushirat Odunayo Ogundairo, Sakiru Morenikeji Erinoso, Adebimpe Oluwafunmilayo Olanloye. Foliar epidermal studies of some Nigerian species of Sida Linn. (Malvaceae). Scholarly Journal of Agricultural Science. 2012; 2(2):18-22.

11. Metcalfe, C.R. and Chalk, L. 1950. Anatomy of the Dicotyledons, Vol. 2. Oxford, pp. 1014-1024.
12. Ayesa Begum, Oliur Rahman Md., Momtaz Begum. Stomatal and Trichome diversity in Senna Mill. from Bangladesh. Bangladesh Journal of Plant Taxonomy. 2014. 21(1): 43-51.

13. Rosario Redonda Martınez, Villasen Jose' Luis, Terrazas Teresa. Trichome diversity in the subtribe Leiboldiinae (Vernonieae, Asteraceae). Journal of the Torrey Botanical Society, 2016; 143(3): 298-310.

14. Krishnakumar K., Rajeena P., Veena V. Study on diversity of foliar trichomes in thirty accessions of okra [Abelmoschus esculentus (L.) Moench.]. Indian Journal of Agricultural Research, 2018. 52(4): 439-443.

15. Antonia-Maria Mărgineanu, Imola Erdelyi-Molnár, Elena Rakosy-Tican Comparative study of trichomes in three parental Solanum species and their somatic hybrids, cultivated in greenhouse or phytotron. Studia Universitatis Babeş-Bolyai Biologia, LX, 2015. 1:7-67.

16. Gulzar Khan, Zhang Faqi, Gao Qingbo, Mashwani Zia-ur-Rehman, Rehman Khalid, Khan Mir Ajab, Chen Shilong. Trichomes diversity in the tropical flora of Pakistan. Journal of Medicinal Plants Research. 2013. 7(22):1587-1592.

17. Anjum Perveen, Muneeba Khan, Mansuri Shazia, Tabassum Tabeer. Morphological studies on trichome of family Asteraceae. International Journal of Biology and Biotechnology. 2016;13 (2): 177-182.

18. Hickey, L.J., 1973. Classification of the architecture of dicotyledonous leaves. American Journal of Botany 60: 17-33.

19. Mick Hanley E., Byron Lamont B., Meredith Fairbanks M., Christine Rafferty M. Plant structural traits and their role in anti-herbivore defence. Perspectives in Plant Ecology, Evolution and Systematics, 2007; 8:157-178.

20. Nighat Shaheen, Mir Ajab Khan, Ghazalah Yasmin, Mushtaq Ahmad, Tariq Mahmood, Muhammad Qasim Hayat, and Muhammad Zafar Foliar epidermal anatomy and its systematic implication within the genus Sida L. (Malvaceae). African Journal of Biotechnology. 2009; $8(20), 5328-5336$.

21. Bhatt A., Naidoo Y., Nicholas A. An investigation of the glandular and non-glandular foliar trichomes of Orthosiphon labiatus N.E.Br. [Lamiaceae]. New Zealand Journal of Botany. 2010. 48(3):153-161.

22. Seyed Talebi Mehdi, Mahdiyeh Majid, Nohooji Majid Ghorbani, Akhani Mahsa. Analysis of trichome morphology and density in Sa/via nemorosa L. (Lamiaceae) of Iran. Botanica. 2018, 24(1): 49-58.

23. Chatri M, Baktiar A, Mansyurdin M, Periadnadi P. Leaf Trichomes Morphology of Hyptis suaveolens (L.) Poit. (Lamiaceae). IOP Conf. Series: Materials Science and Engineering. 2018. 335(2018)012020.

24. Bosco Lawarence, Murugan K. Morphological and anatomical variations of the selected species of Osbeckia L. (Melastomataceae). International Journal Pharmaceutical Sciences and Research, 2019; Vol. 10(1): 320-328.

25. Osuji, Onyewuonyeoma Julian, Ajah, Florence Obiageri, Relevance of foliar epidermal characters in the delimitation of three forms of Elaeis guineensis (Jacq.) American Journal of Research Communication. 2016. 4(9): 180-189.

26. Zhi-Yao Ma, Jun Wen, Stefanie Ickert-Bond M., Chen Long-Qing, Liu Xiu- Qun. Morphology, Structure and Ontogeny of Trichomes of the Grape Genus (Vitis, Vitaceae) Frontiers in Plant Science. 2016. Volume 7. Article 704:1-14.

27. Nighat Shaheen, Mir Ajab, Yasmin Ghazalah, Qasim Muhammad Hayat. Diversity of Foliar Trichomes and Their Systematic Relevance in the Genus Hibiscus (Malvaceae). International Journal of Agriculture \& Biology. 2009. 11(3):279-284.

28. Satish Chandra, D.S. Rawat, Smriti Raj Verma, Priyanka Uniyal. Trichome diversity of the family Caryophyllaceae from Western Himalaya and their taxonomic implication. The Journal of the Society for Tropical Plant Research. 2019. 6(3): 397- 407

29. Jayanthi Kamala P. D., Ravindra M. A., Kempraj Vivek, Roy T. K., Shivashankara K. S., Singh T. Morphological diversity of trichomes and phytochemicals in wild and cultivated eggplant species. 2018.75(2): 265-272.

30. Elvin, M. A., Kelley, R. B., \& Drew, B. T. Trichome morphology relates to taxonomic diversity in Monardella (Lamiaceae) in the lower Snake River Watershed of Idaho and Oregon, USA: Taxonomic studies in Monardella (Lamiaceae) VI. Journal of the Torrey Botanical Society. 2019. 146(4): 299-313. 